Boštjan Laharnar

Miha Mlinar

\title{
Prazgodovinski srebrni daritveni ploščici s Šentviške planote
}

\section{KRATKA GEOGRAFSKO-ZGODOVINSKA PREDSTAVITEV}

Šentviška planota je kraška planota v severozahodni Sloveniji, ki leži med dolinama spodnjih tokov Idrijce in Bače. Najstarejše posamezne arheološke najdbe $z$ območja so iz bronaste dobe, intenzivnejšo poselitev pa nakazujejo železnodobna najdišča. $\mathrm{V}$ železni dobi je planota $\mathrm{z}$ dobrimi pogoji za razvoj živinoreje, poljedelstva in sadjarstva ter nahajališči železove rude predstavljala

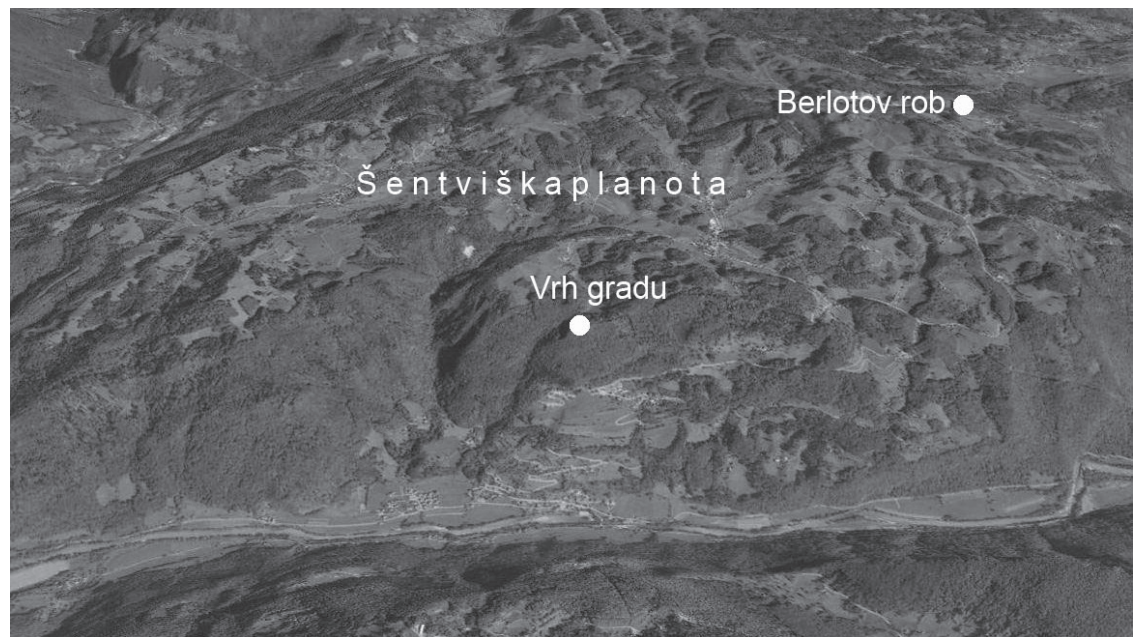

SLIKA 1: Šentviška planota in položaj najdišč Vrh gradu pri Pečinah in Berlotov rob. 
gospodarsko zaledje posoškemu središču na Mostu na Soči. ${ }^{1} \mathrm{Ni}$ zanemarljivo dejstvo, da je glavna povezava med Posočjem in osrednjo Slovenijo od železne dobe do 19. stoletja potekala prav prek Šentviške planote ${ }^{2}$ in ne po dolini reke Idrijce kot danes.

\section{NAJDIŠČE VRH GRADU PRI PEČINAH IN SREBRNA DARITVENA PLOŠČICA}

Vrh gradu leži zahodno od vasi Pečine in je med pomembnejšimi arheološkimi najdišči na Šentviški planoti. Najdišče predstavlja ozek skalnat pomol nad grapo hudourniškega potoka Kostanjevica. Nahaja se prav na robu planote, ki nato strmo prehaja proti dolini Idrijce. O obstoju arheološkega najdišča priča že pripoved domačinov, da naj bi na tem mestu nekoč stal grad. Zaradi značilnega toponima je na lokacijo prvi, davnega 1853 leta, opozoril župnik Tomaž Rutar. Danes je na najdišču razpoznati umetno zasekane terase, kjer so najverjetneje stale stavbe, ter obrambni okop na vzhodnem, pristopnem slemenu. ${ }^{3}$ Najdišče so v zadnjih desetletjih obiskovali različni ljubiteljski »arheologi« in nestrokovno izkopali številne najdbe iz bronaste in železne dobe ter iz rimskega obdobja. ${ }^{4}$ Najdbe nakazujejo, da je bil v sklopu železnodobne in morda antične naselbine tudi daritveni prostor oziroma kultno mesto. ${ }^{5}$ Med značilne votivne najdbe sodijo daritvene ploščice. Na Vrhu gradu je bila izkopana srebrna $^{6}$ daritvena ploščica pravokotne oblike $(3.7 \mathrm{~cm} \times 3.3 \mathrm{~cm} \times 0.1 \mathrm{~cm})$, ki jo je najditelj leta 2008 prinesel v Tolminski muzej in je hranjena $\mathrm{z}$ inv. št. TM 1506. $\mathrm{S}$ hrbtne strani je ob robovih okrašena $\mathrm{z}$ iztolčenimi bunčicami, v sredini pa $s$ krogcem in bunkico. Med sredinskim okrasom in robom je napisno polje $\mathrm{z}$ iztolčenimi črkami v venetski pisavi. Luknjica med sredinskim krogcem in bunkico je po pripovedovanju najditelja nastala s konico krampiča med izkopom predmeta. ${ }^{7}$

Pomembnost ploščice je večplastna in jo lahko obravnavamo z več vidikov. Ploščica je srebrna in je bila kot taka do najdbe $\mathrm{z}$ najdišča Berlotov rob, o kateri bo govor v nadaljevanju, brez primerjave.

Po obliki in okrasu je ploščica primerljiva nekaterim bronastim primerkom iz svetišč in kultnih mest. Oblikovno sorodna skupina ploščic izvira $\mathrm{Z}$

1 Laharnar in Mlinar, »erovca at Šentviška planota «, 476-77; »Železnodobno grobišče v Jerovci na Šentviški planoti«, 18-19.

2 Kofol, »Po sledeh nekdanjih poti«, 77-78.

3 Laharnar in Mlinar, »K Minervi in Hefajstvu na Vrh gradu«, 24.

4 Božič, »Tre insediamenti minori«, 75, Fig. 5-6; Laharnar in Mlinar, »K Minervi in Hefajstvu na Vrh gradu«.

5 Laharnar in Mlinar, »K Minervi in Hefajstvu na Vrh gradu«; Božič, »Prazgodovinske najdbe s Tonovcovega gradu«, 265.

6 Ploščica je iz skoraj čistega srebra (99.1-99.3\%).

7 Mlinar in Crevatin, "Laminetta d'argento «; Božič, "Prazgodovinske najdbe s Tonovcovega gradu«, 258 . 
Gurine v zgornji Ziljski dolini, ki je bila v železni in rimski dobi pomembna naselbina s svetiščem. Nekatere izmed tamkajšnjih bronastih ploščic imajo venetske napise, druge so le figuralno ali geometrijsko okrašene. ${ }^{8}$ Najdbi z Vrha gradu je po obliki in okrasu, ne pa po velikosti, najbolj podobna ploščica z napisom ob robu in sredinskim motivom krožno razporejenih iztolčenih bunčic in bunkice. ${ }^{9}$ Votivne ploščice $\mathrm{z}$ venetskimi napisi z Gurine so časovno umeščene v 2. ali 1. st. pr. n. št. ${ }^{10}$

Dobra primerjava je tudi ena izmed najmanj šestih odkritih daritvenih ploščic s svetišča na pobočju Gradiča nad Kobaridom. ${ }^{11}$ Ta sicer nima venetskega napisa, pač pa identičen okras bunčic, bunkice in krogca. ${ }^{12} \mathrm{Za}$ datacijo ploščic z Gradiča je pomembna figuralno okrašena ploščica s centralno podobo konjenika s sulico, ki je po robu prav tako okrašena $\mathrm{z}$ iztolčenimi bunčicami. ${ }^{13}$ Predlogo za upodobitev konjenika je verjetno predstavljal republikanski denarij, kovan v letih 114-113 pr. n. št. ${ }^{14}$ Z Gradiča izvira tudi odlomek daritvene ploščice $\mathrm{z}$ venetskimi črkami ${ }^{15}$ in $\mathrm{z}$ okrasom bunčic, ki glede na statigrafske podatke verjetno sega $\mathrm{v}$ zadnja desetletja 1 . st. pr. n. št. ${ }^{16}$

Po skoraj kvadratni obliki, razporeditvi napisa in okrasu robov je ploščici z Vrha gradu primerljiva bronasta ploščica s karnijskega višinskega naselja in kultnega mesta Colle Mazéit pri Verzegnisu. ${ }^{17}$

Važen vidik predstavlja študij venetskega napisa na ploščici, ki je pomemben za preučevanje osebnih imen, jezika in problematike etnične pripadnosti posoške železnodobne skupnosti. Franco Crevatin je napis razbral kot zapis z dvočlensko imensko formulo, sestavljeno iz pravega (ime darovalca) in drugega imena, izpeljanega po očetovem imenu. Osebnemu imenu darovalca Voturos je Crevatin našel primerjavo v imenu Voturi, ki ga Plinij (Nat. Hist. 5.146) navaja med imeni keltskih Galatov. V imenu Vol/pl/pknics ali $\mathrm{Vol} / \mathrm{pl}$ pnijs, izpeljanem po očetovem imenu, pa je prebral venetizirano ime na keltski osnovi. ${ }^{18}$

Iz navedenih primerjav pečanske ploščice sledi, da se taka oblika daritvenih ploščic pojavlja znotraj svetišč in kultnih mest na severnih in severovzhodnih, hribovitih obrobnih območjih vpliva venetske kulture (Gurina, Kobarid,

8 Jablonka, Die Gurina bei Dellach im Gailtal, 207-12.

9 Id., 170, Taf. 124: 1, Taf. 131: 1

10 Id., 170.

11 Osmuk, »Kobarid od prazgodovine do antike«, 12; »Plaquette votive de Kobarid«, 17; Božič, »Prazgodovinske najdbe s Tonovcovega gradu«, 256.

12 Božič, »Prazgodovinske najdbe s Tonovcovega gradu«, sl. 6.17: 1.

13 Osmuk, "Plaquette votive de Kobarid«, fig. 2; Božič, "Prazgodovinske najdbe s Tonovcovega gradu«, 257, sl. 6.17: 8

14 Osmuk, "Plaquette votive de Kobarid«; Božič, "Prazgodovinske najdbe s Tonovcovega gradu«, 258.

15 Eichner in Nedoma, »Neue vorrömische Inschriften aus Westslowenien«, 73, Abb. 5.

16 Turk et al., "New Pre-Roman inscriptions from Western Slovenia«.

17 Crevatin, "Nuovi testi venetici provenienti dal Friuli«, 71-72; »Le iscrizioni venetiche del Friuli«, 116-17; Vannacci Lunazzi, "L'insediamento di Colle Mazéit a Verzegnis«, 152; Donat et al., »Pratiche cultuali nel Friuli settentrionale«, 96.

18 Mlinar in Crevatin, »Laminetta d'argento«, 294. 
Colle Mazéit, Vrh gradu). Tu so se prepletali keltsko-venetski vplivi in lokalne severnojadransko-jugovzhodnoalpske tradicije. Na podobno mešanje vplivov kaže tudi analiza napisa na ploščici z Vrha gradu.

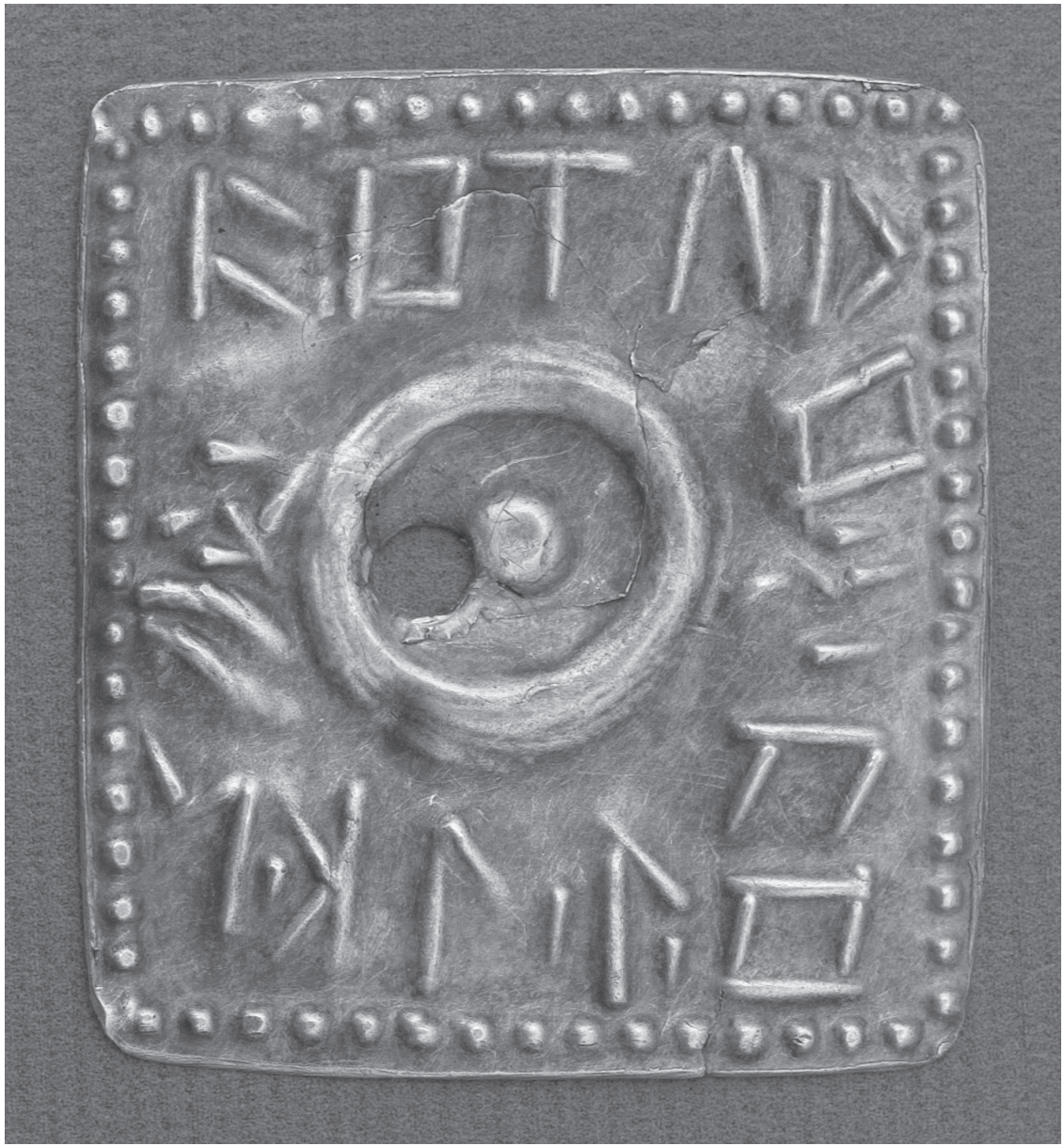

SLIKA 2: Srebrna daritvena ploščica z Vrha gradu (foto M. Grego, risba N. Grum).

\section{NAJDIŠČE BERLOTOV ROB IN SREBRNA DARITVENA PLOŠČICA}

Med vasema Prapetno Brdo in Šentviška Gora na Šentviški planoti se dviga izrazita gozdnata, kopasta skalna vzpetina, katere vrh so kraški pojavi preoblikovali v zanimivo razbrazdano in nazobčano stožčasto naravno kuliso. Hrib je prepreden $z$ visokimi skalami, škrapljami, previsnimi stenami in brezni. Kljub skoraj neprehodnemu terenu so vmes izdelane umetne poravnave in terase, na katerih domnevamo ostanke objektov. Koncentracije kamenja v polkrožnem vencu obdajajo najdišče s severne strani, med njimi proti vrhu hriba vodi ozka 
in strma pot. Le $\mathrm{z}$ arheološkimi izkopavanji bi pokazali, ali gre $\mathrm{v}$ tem primeru za ostanke obzidja ali morda za kultna kamnita nasutja, kakršna so raziskali na nekaterih najdiščih v Alpah. ${ }^{19}$

Tudi z Berlotovega roba izvirajo številne arheološke najdbe, ki so jih izkopali ljubiteljski zbiralci starin s pomočjo detektorja kovin. Del teh najdb sta uspela v svoje zbirke pridobiti Narodni muzej Slovenije in Tolminski muzej. Čeprav so bile nekatere v zadnjih letih objavljene, ostaja glavnina neobjavljena. Med objavljenim gradivom je odlomek bronaste situle $\mathrm{z}$ napisom v venetski pisavi iz 4. st. pr. n. št., ${ }^{20}$ srebrna ovratnica s konca 2. ali iz 1. st. pr. n. št., ${ }^{21}$ sponka iz starejše železne dobe ${ }^{22}$ ter dve zgodnjerimski sponki. ${ }^{23}$ Omenjene najdbe nakazujejo obljudenost najdišča od druge polovice 1. tisočletja pr. n. št. do začetka rimske dobe. Nenavadne topografske značilnosti najdišča, veliko število raznovrstnih, dobro ohranjenih kovinskih najdb in nekateri izjemni predmeti nakazujejo, da tod ni bila navadna naselbina, ampak zelo verjetno železnodobno kultno mesto oziroma sveto mesto v naravi. Fenomen prazgodovinskih in antičnih kultnih mest, kjer so darovali nakit, orožje, orodje, posodje in novce na krajih, kjer narava izrazito kaže svojo moč in domišljijo, kot so brezna, jame, reke, jezera, sotočja, izviri, prelazi in naravni mostovi, je dobro dokumentiran na širšem alpskem prostoru. ${ }^{24}$

Med gradivom z Berlotovega roba Narodni muzej Slovenije hrani tudi okroglo, nekoliko poškodovano ploščico iz srebne pločevine s premerom 4.3 cm (inventarna številka P 27225). Po ogledu najdišča s prijateljem najditelja, ki je najdbo predal muzeju, smo ugotovili le približno lokacijo najdbe. Vsekakor pa naj bi bila najdena znotraj območja najdišča. Ploščica je okrašena s krožci s pikicami, bunčico in krajcema (lunicama). Izdelovalec je okras domiselno razporedil v jasno ikonografsko pripoved. Bunčica je izdelana na sredini ploščice, obrobljajo jo pikice, ki so razporejene tudi po njenem robu in tvorijo še štiri notranje krake. Štirje kraki pikic delijo polje ploščice na štiri enake medprostore. Dva medprostora imata iztolčena krajca (lunici), dva pa izdelano luknjico. Z opazovanjem pod mikroskopom smo ugotovili, da sta bili tudi na mestih, kjer sta luknjici, sprva iztolčeni lunici (krajca ?). To kaže, da je bila ploščica naknadno pričvrščena ali pribita na neko podlago.

Ploščici z Berlotovega roba nismo našli primerjave. Med vzhodnoalpskimi in severnojadranskimi železnodobnimi skupnostmi zadnjih stoletij 1 . tisočletja je sicer pogosto okraševanje okroglih ploščic, obeskov ter faler z iztolčevanjem pikic in bunčic, vendar so te izdelane iz bronaste pločevine. Tak

19 Gleirscher, »Brandopferplätze in den Ostalpen«, 99, t. 151: 3-4.

20 Turk et al., "New Pre-Roman Inscriptions from Western Slovenia«, 57-59 (kot najdišče Posočje).

21 Turk, »Keltski bojevniki«, 99, kat. št. 5 (kot najdišče Posočje).

22 Laharnar in Mlinar, „Železnodobno grobišče v Jerovci na Šentviški planoti«, 17.

23 Istenič, "Brooches of the Alesia group in Slovenia«, 192, 196, 212, pl. 1: 5, 12 (kot najdišče Šentviška planota).

24 Zemmer-Plank in Sölder 2002, Kult der Vorzeit in den Alpen; Božič, "Prazgodovinske najdbe s Tonovcovega gradu«, 241-6o. 
primer so denimo falera iz Škocjanskega zaklada, ${ }^{25}$ faleri z (domnevno) Gradišča na Čepni blizu Knežaka, ${ }^{26}$ falera z Ambroževega gradišča pri Slavini ${ }^{27}$ in obeski iz Bodreža na Goriškem. ${ }^{28}$ Podobno okrašene okrogle bronaste ploščice najdemo tudi v Venetu, ${ }^{29}$ Lombardiji $^{30}$ na Tirolskem ${ }^{31}$ in vse do Ticina v Švici. $^{32}$ Poleg dejstva, da je ploščica z Berlotovega roba srebrna, je izjemno redek tudi motiv luninih krajcev. Med gradivom z najdišč pozne prazgodovine smo $\mathrm{v}$ srednjeevropskem prostoru našli soroden motiv le na gumbu (?) iz poznobronastodobne in železnodobne naselbine Monte Castejon v Venetu. ${ }^{33}$ Gumb izvira iz izkopavanj v drugi polovici 19. st. in je bil odkrit skupaj s sponkami, ovratnico in obeskom, značilnimi za zadnja stoletja 1. tisočletja pr. n. št. ${ }^{34}$ in z dobrimi primerjavami tudi med najdbami na Berlotovem robu.

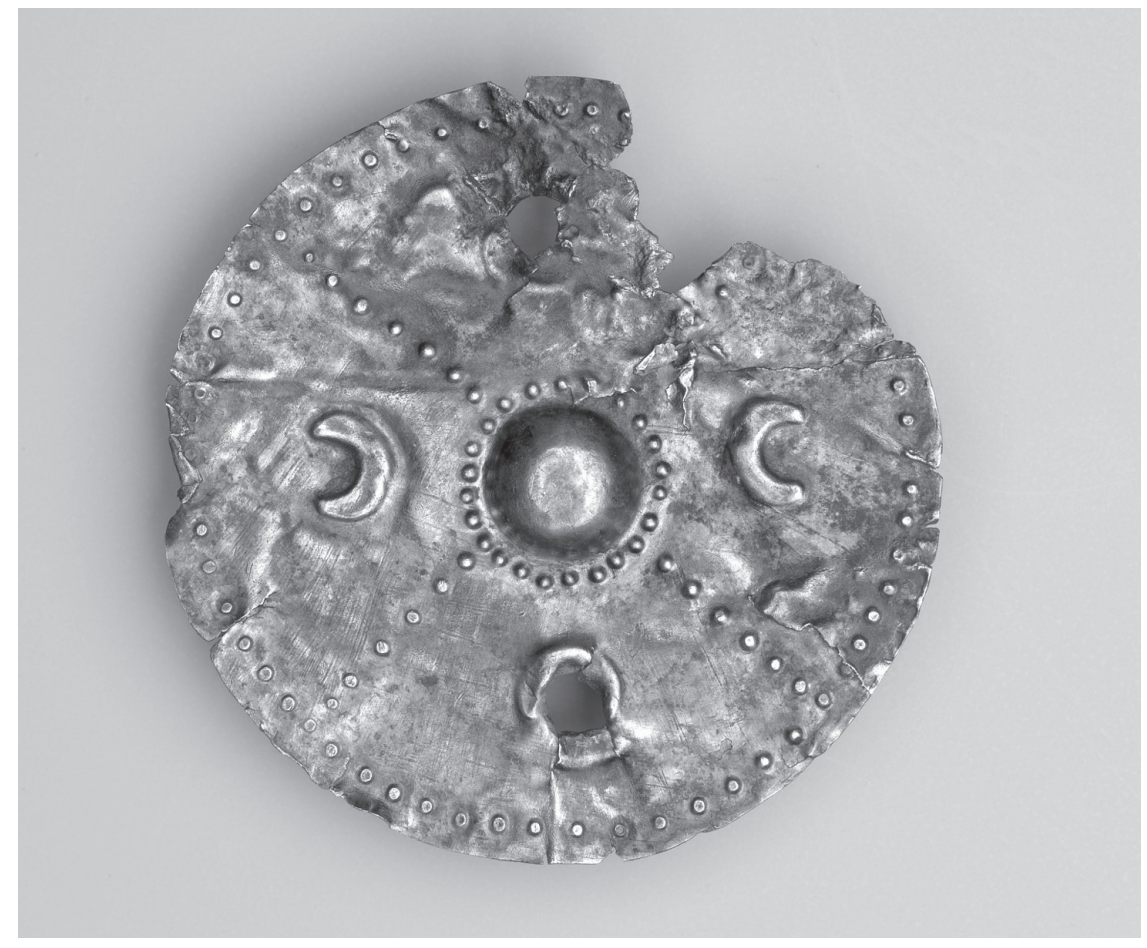

SLIKA 3: Srebrna daritvena ploščica z Berlotovega roba (foto T. Lauko, risba I. Murgelj).

25 Ruaro Loseri, »Il tesoretto di San Canziano«, 150, fig. 26A.

26 Guštin, Notranjska, 33, t. 4: 4-5.

27 Horvat, »Notranjska na začetku rimske dobe«, 196, t. 10: 16.

28 Guštin, Posočje in der jügeren Eisenzeit, 12, 142, t. 40: 19-21.

29 Carancini, »Falere«, 61, sl. 10: 24-25.

30 Rapi, La seconda età del ferro nell' area di Como e dintorni, 65, t. 31: 230.

31 Sölder, Ur-und Frügeschichte von Innsbuck, 213: kat. št. 56.

32 Schindler, Der Depotfund von Arbedo, 112, 427, t. 37: 766-67.

$33 \mathrm{Za}$ informacijo o najdbi sva hvaležna Andreju Preložniku.

34 Salzani, Colognola ai Colli. 
Razporeditev okrasa na ploščici z Berlotovega roba, ki deli polje ploščice na štiri enake dele $z$ osrednjo bunčico in štirimi lunicami, nas napeljuje na domnevo, da je izdelovalec upodobil mesečni ciklus. Osrednja bunkica morda predstavlja Zemljo, lunice pa z Zemlje najbolj opazno spremembo pri Luninem gibanju, to so Lunine mene ali faze. Že najstarejša ljudstva so ugotovila, da t. i. sinodski mesec (čas med dvema enakima fazama Lune) približno ustreza menstrualnemu ciklusu, in so z opazovanjem menjavanja luninih men merila čas. V simbolizmu mnogih kultur sta imela in imata pomembno vlogo prvi in zadnji lunin krajec, ki čez leto najbolj očitno spreminjata lego glede na horizont. Pojav usmerjenosti rogov prvega krajca v odvisnosti od letnega časa je namreč omogočal približno ugotavljanje letnih časov in napovedovanje določenih sprememb v naravi. ${ }^{35}$

\section{SREBRO, PISAVA IN ASTRONOMIJA PRI ŽELEZNODOBNIH PREBIVALCIH POSOČJA}

Prebivalstvo mlajše železne dobe (od okrog 300 pr. n. št. do rimske zasedbe) Posočja je v arheologiji opredeljeno s pojmom idrijske skupine. ${ }^{36}$ Povezovanje materialnih ostankov $\mathrm{z}$ določeno etnično skupino je zelo težavno. V stroki sta najbolj prisotni mnenji, ki postavljata $\mathrm{v}$ predrimskodobno Posočje keltske Ambisonte ${ }^{37}$ in Karne. ${ }^{38}$ Poleg nekaterih elementov materialne kulture in razširjenosti venetske pisave ${ }^{39}$ je bil v Posočju znaten tudi vpliv Venetov. Nenazadnje Crevetinovo branje napisa na pečanski ploščici govori o prepletu keltskih in venetskih prvin. ${ }^{40}$ Podobno zapleteno formulacijo uporabljajo avtorji tudi v razlagah mlajšeželeznodobnih arheoloških sledov v Karniji, ki naj bi jo naseljevali keltski Karni ob prisotnosti venetskega substrata. ${ }^{41} \mathrm{Na}$ tem mestu nočemo pregloboko posegati v težavno razpravo o prisotnosti Keltov v Posočju, ki jo je ponovno razvnelo nedavno presenetljivo odkritje zakopa konjskih okostij in keltskega orožja ter drugih najdb v Kobaridu, ${ }^{42}$ vendar nam srebrna ploščica z Berlotovega roba omogoča zanimive asociacije. Če sledimo domnevi, da je izdelovalec na ploščici upodobil Lunine mene in Zemljo, ne moremo mimo navedb antičnih avtorjev o nekaterih astronomskih predstavah pri Keltih.

Gaj Julij Cezar je leta 45 pr. n. št. uvedel julijanski koledar. Ta je temeljil na sončevem letu in ostal v uporabi vse do uveljavitve današnjega gregorijanskega koledarja pod papežem Gregorjem XIII leta 1582. Zanimiva je Cezar-

35 Šprajc, Arheoastronomija, 26-27.

36 Po najdišču Idrija pri Bači.

37 Šašel, „Zur Erklärung«, Opera selecta, 288-97; Guštin, »Carnium (Kranj, Slowenien)«, 449, sl. 1.

38 Božič, "Die Erforschung der Latènezeit«, 203; Istenič, „Evidence for a very late Republican siege «, 84; Horvat in Bavdek, Okra, 132.

39 Turk et al., »New Pre-Roman Inscriptions from Western Slovenia«, 48, sl. 1.

40 Mlinar in Crevatin, »Laminetta d'argento«, 293-94.

41 Vitri in Oriolo, I Celti in Carnia; Horvat in Bavdek, Okra, 132.

42 Mlinar in Gerbec, Keltskih konj topòt. 
jeva notica v Galski vojni, kjer nekoliko zviška ocenjuje: »Galci mislijo, da so potomci boga Dita, in se sklicujejo na izročila druidov. Zato določajo čas ne po dnevih, temveč po nočeh. Rojstne dneve, začetke mesecev in let štejejo tako, da se začenjajo $\mathrm{z}$ nočjo, ki ji sledi dan. « ${ }^{43}$ Podobno pri Pliniju beremo, da druidi začenjajo mesec in leto s šesto luno (sexta luna), ${ }^{44}$ medtem ko Strabon poroča o velikem pomenu polne lune pri Keltih z Iberskega polotoka in njihovih severnih sosedih. ${ }^{45}$ Smemo torej domnevati, da je tudi pri železnodobnih prebivalcih Posočja pomembno vlogo pri razumevanju štetja časa in celo pri organizaciji prostora igrala Luna? Na to morda kaže zanimiv indic z najdišča Tonovcov grad pri Kobaridu, kjer orientacija dveh poznoantičnih cerkva proti vzhodu približno ustreza vzhajališču Lune ob največjem južnem ekstremu. Usmeritve proti velikim in malim lunarnim ekstremom so pogoste na evropskih prazgodovinskih najdiščih, zato Čavalova in Šprajc dopuščata možnost, da sta bili cerkvi postavljeni na ruševinah predkrščanskega svetišča. ${ }^{46}$ Temu v prid govori tudi analiza drobnih najdb. ${ }^{47}$

Najdbe z železnodobnih kultnih mest in grobišč v Posočju nakazujejo koncentracijo znanja takratnih prebivalcev. To znanje je združevalo rokodelsko spretnost izdelovanja lepih predmetov iz srebra, uporabo pisave in denarja:

- le z najdišč v Posočju poznamo srebrne pletene ovratnice s tremi vozli, ki so jih sicer v bronasti izvedbi nosili od Veneta in Furlanije, prek zahodne Slovenije do Istrskega polotoka; ${ }^{48}$ - vsaj od sredine 2 . stoletja pr. n. št. se v Posočju že pojavljajo veliki in mali keltski srebrniki skupaj z rimskim republikanskim denarjem; ${ }^{49}$

- srebrni sta tudi obe tukaj obravnavani votivni ploščici, kar nima primerjav. Naj omenimo, da med desetinami daritvenih ploščic iz svetišča boginje Reitie v Estah ni nobene srebrne; ${ }^{50}$

- nekatere značilnosti predrimskih napisov iz Posočja kažejo na uporabo lokalne različice venetske pisave od 4 . st. pr. n. št; ${ }^{51}$

- končno morda tudi ikonografija srebrne votivne ploščice z Berlotovega roba in morebitna alineacija železnodobnega kultnega mesta na Tonovcovem gradu kažeta na dojemanje astronomskih pojavov, kot so Lunine mene in lunarni ekstremi, v kultu in pri organizaciji prostora.

V kolikšni meri so bila našteta znanja razširjena, je težko oceniti. Vsaj uporaba pisave in astronomija sta bili verjetno $\mathrm{v}$ domeni vzdrževalcev in vo-

43 Caes., Gall. 6.18.

44 Plin., NH 16.95.

45 Strab. 3.4.16.

46 Čaval in Šprajc, »Astronomska orientacija cerkva na Tonovcovemu gradu«, 251.

47 Božič, »Prazgodovinske najdbe s Tonovcovega gradu«, 241-6o; že prej o tem domnevali tudi:

Ciglenečki, Tonovcov grad pri Kobaridu, 7-8; Mlinar, "Kobariška kultna krajina«, 23.

48 Guštin, Posočje in der jüngeren Eisenzeit, 47; Božič, "Silver Jewellery of Iron Age Women«, 833-37.

49 Kos in Žbona Trkman, »A Hoard of Roman Republican«, 271-82.

50 Capuis in Chieco Bianci, Lamine figurate I.

51 Eichner in Nedoma, »Neue vorrömische Inschriften aus Westslowenien«, 65-75. 
diteljev kultnih mest. Kot kaže, so posoška kultna mesta in svetišča z vzpostavitvijo rimske nadoblasti doživela različno usodo. Nekatera so bila dejavna še dolgo v antično in v kasnejše obdobje. Taka primera sta kobariška Tonovcov grad in Gradič. ${ }^{52}$ Tudi Vrh gradu je bil obljuden še v rimski in zlasti v pozni rimski dobi, vendar je kultni značaj najdišča $\mathrm{v}$ tem obdobju težje ugotovljiv. Povsem drugače je na Berlotovem robu, kjer so najmlajše najdbe iz avgustejske dobe in morda še iz prvih desetletji 1. st. n. št. Nekatere med njimi so tesno povezane $\mathrm{z}$ rimsko vojsko. Rimski fibuli na šarnir ${ }^{53}$ ter še nekatere sočasne rimske vojaške najdbe (neobjavljeno) razumemo v kontekstu podobnih zbirov najdb s Cerkljanskega, kjer se interpretirajo kot sledovi spopadov med Rimskimi osvajalci in domačini. ${ }^{54} \mathrm{Na}$ osnovi tega domnevamo, da so Rimljani prekinili stoletni kult na Berlotovem robu, ki je bil gotovo pomemben del identitete tukajšnje železnodobne skupnosti. Vojaški, politični in ekonomski nadvladi je v tem primeru sledila tudi simbolna nadvlada.

\section{BIBLIOGRAFIJA}

Božič, D. »Die Erforschung der Latènezeit in Slowenien seit Jahr 1964/Raziskovanje latenske dobe na Slovenskem po letu 1964. «Arheološki vestnik 50 (1999): 189-213.

. »Tre insediamenti minori del gruppo protostorico di Idrija pri Bači dell'Isontino. « V: S. Santoro, ur., Studio e conservazione degli insediamenti minori romani in area alpina, Studi e Scavi 8 (1999): 71-79.

„Silver jewellery of Iron Age women in the Friuli Plain and in the Soča Region. "V: M. Blečić et al., ur., Scripta praehistorica in honorem Biba Teržan, Situla 44, 829-41. Ljubljana: Narodni muzej Slovenije, 2007.

_. »Prazgodovinske najdbe s Tonovcovega gradu in železnodobna kultna mesta v Posočju/Prehistoric finds from Tonovcov grad and Iron Age cult places in Posočje.« V: Z. Modrijan in T. Milavec, Poznoantična utrjena naselbina Tonovcov grad pri Kobaridu, Najdbe/Late Antique fortified settlement Tonovcov grad near Kobarid, Finds, Opera Instituti Archaeologici Sloveniae 24, 239-77. Ljubljana: ZRC SAZU, 2011.

Calzavara Capuis, L., in A. M. Chieco Bianci. Le lamine figurate del santuario di Reitia a Este: (scavi 1880-1916 e 1987-1991)/Die figural verzierten Votivbleche aus dem Reitia-Heiligtum von Este: (ausgrabungen 1880-1916 und 1987-1991). Studien zu vor- und frühgeschichtlichen Heiligtümern 6 /1, Il santuario di Reitia a Este 5/1. Mainz am Rhein: P. von Zabern, 2010. Carancini, G. L. »Falere.« V: R. Peroni et al., Studi sulla cronologia delle civiltà

52 Mlinar, »Kobariška kultna krajina«, 22-23.

53 Istenič, "Brooches of the Alesia group in Slovenia", 192, 196, 212, pl. 1: 5, 12.

54 Istenič, »Evidence for a very late Republican siege«, 77-86. 
di Este e Golasecca. Origines: studi e materiali pubblicati a cura dell'Istituto Italiano di Preistoria e Protostoria. Firenze: Istituto Italiano di Preistoria e Protostoria, 1975.

Ciglenečki, S. Tonovcov grad pri Kobaridu. Arheološko najdišče. Vodnik. Ljubljana: Arheološki inštitut Znanstvenoraziskovalnega centra SAZU, 1997.

Crevatin, F. »Nuovi testi venetici provenienti dal Friuli.» Incontri Linguistici 18 (1995): 71-77.

—. »Le iscrizioni venetiche del Friuli.« V: G. Bandelli in F. Fontana, ur., Iulium Carnicum, Centro alpino tra Italia e Norico dalla protostoria alleta imperiale, Atti del Convegno, 115-26. Roma: Ed. Quasar, 2001.

Čaval S., in I. Šprajc. »Astronomska orientacija cerkva na Tonovcovemu gradu.« V: Z. Modrijan in T. Milavec, Poznoantična utrjena naselbina Tonovcov grad pri Kobaridu, Najdbe/Late Antique fortified settlement Tonovcov grad near Kobarid, Finds, Opera Instituti Archaeologici Sloveniae 24, 247-55, Ljubljana: ZRC SAZU, 2011.

Donat, P., et al. »Pratiche cultuali nel Friuli settentrionale tra tarda età del ferro e prima età imperiale, Alcuni esempi (Italia).« V: S. Groh in H. Sedlmayer, ur., Blut und Wein, Keltisch-römische Kultpraktiken, Protohistoire Europeene 10, 91-117. Montagnac: Ed. Monique Mergoil, 2007.

Eichner, H., in R. Nedoma. »Neue vorrömische Inschriften aus Westslowenien: epigrafische und Linguistische Evidenz.« V: G. Tiefengraber, B. Kavur in A. Gaspari, ur., Celtic Studies II, Protohistoire européenne 11, 65-76. Montagnac: Ed. Monique Mergoil, 2009.

Gleirscher, P. »Brandopferplätze in den Ostalpen.« V: P. Gleirscher, H. Nothdurfter in E. Schubert, ur., Das Rungger Egg, Römisch-Germanische Forschungen 61, 173-264. Mainz am Rhein: Philipp von Zabern, 2002.

Guštin, M. Notranjska. K začetkom železne dobe na severnem Jadran/Zu den Anfängen der Eisenzeit an der nördlichen Adria. Katalogi in monografije 17. Ljubljana: Narodni muzej Slovenije, 1979.

—. Posočje in der jüngeren Eisenzeit/Posočje v mlajši železni dobi. Katalogi in monografije 27. Ljubljana: Narodni muzej Slovenije, 1991.

—. „Carnium (Kranj, Slovenia): insediamento dei Carni.« V: S. Casini, ur., »Il filo del tempo«, Studi di preistoria e protostoria in onore di Raffaele Carlo de Marinis, Notizie Archeologiche Bergomensi 19, 44758. Bergamo: Civico Museo archeologico, 2011.

Horvat, J. »Notranjska na začetku rimske dobe: Parti pri Stari Sušici, Ambroževo gradišče in Baba pri Slavini/Notranjska (Inner Carniola) at the beginning of the Roman Period: Parti near Stara Sušica, Ambroževo gradišče and Baba near Slavina.» Arheološki vestnik 46 (1995): 177216.

Horvat, J., in A. Bavdek. Okra. Vrata med Sredozemljem in Srednjo Evropo/ 
Ocra. The gateway between the Mediterranean and Central Europe. Opera Instituti archaeologici Sloveniae 17. Ljubljana: ZRC SAZU, 2009.

Istenič, J. »Brooches of the Alesia group in Slovenia/Fibule skupine Alesia v Sloveniji.« Arheološki vestnik 56 (2005): 187-212.

»Evidence for a very late republican siege at Grad near Reka in Western Slovenia." Carnuntum Jahrbuch 2005 (2005): 77-87.

Jablonka, P. Die Gurina bei Dellach im Gailtal. Siedlung, Handelsplatz und Heiligtum. Aus Forschung und Kunst 33. Klagenfurt: Geschichtsverein für Kärnten, 2001.

Kofol, K. »Po sledeh nekdanjih poti.« V: J. Jakopič, ur., Zbornik Šentviške planote, 75-88. Ponikve: Župnija Ponikve, 1998.

Kos, P., in B. Žbona Trkman. "A hoard of Roman Republican and Norican coins from the vicinity of Kobarid.« Arheološki vestnik 60 (2009): 271-81.

Laharnar, B., in M. Mlinar. »Jerovca at Šentviška planota: newly discovered Iron Age cemetery.« Annales. Seria historia e sociologia 18, št. 2 (2008): 471-78.

—. »K Minervi in Hefajstvu na Vrh gradu.« EPIcenter 12, št. 1-2 (2011): 24-25.

—. .Železnodobno grobišče v Jerovci na Šentviški planoti.« Goriški letnik 35 (2011, izid 2013): 9-32.

Mlinar, M. »Kobariška kultna krajina.« V: D. Fortunat Černilogar, ur., Naplavine obsoške zgodovine, Vodnik po stalni razstavi Tolminskega muzeja, 22-23. Tolmin: Tolminski muzej, 2011.

Mlinar, M., in F. Crevatin. »Laminetta d'argento con iscrizione venetica proveniente da Vrh Gradu sull'altipiano di Šentviška planota in Slovenia occidentale.« V: G. Borghello in V. Orioles, ur., Per Roberto Gusmani, Linguistica storica e teorica, Studi in ricordo 2, Tomo 1, 287-94. Udine: Forum, 2012.

Mlinar, M., in T. Gerbec. Keltskih konj topòt/Hear the Horses of Celts. Katalog razstave. Tolmin: Tolminski muzej, 2011.

Osmuk, N. »Kobarid od prazgodovine do antike.« V: N. Osmuk et al., Kobarid, 9-16. Kobarid: Kobariški muzej, 1997.

—. —Plaquette votive de Kobarid (SI), inspirée d'un denier républicain.« Instrumentum 7 (1998): 17.

Rapi, M. La seconda età del ferro nell'area di Como e dintorni. Materiali La Tène nelle collezioni del Civico Musoe Archeologico P. Giovio. Archeologia dell'Italia settentrionale 11. Como: Comune di Como, 2009.

Ruaro Loseri, L. »Il tesoretto di San Canziano. « V: Preistoria del Caput Adriae, Il Catalogo, 150-51. Udine: Istituto Per l’ Enciclopedia Friuli Venezia Giulia, 1983.

Salzani, L. Colognola ai Colli. Rivista di Studi Etruschi 44. Firenze: Istituto 
nazionale di studi Etruschi ed Italici, 1976.

Schindler, M. P. Der Depotfund von Arbedo TI und die Bronzedepotfunde des Alpenraums vom 6. bis zum Beginn des 4. Jh. v. Chr./Il ripostiglio di Arbedo TI e i ripostigli di bronzi della regione alpina dal VI all'inizio del IV sec. a. C. Antiqua 30. Basel: Schweizerische Gesellschaft für Urund Frühgeschichte, 1998.

Sölder, W, ur. Ur- und Frühgeschichte von Innsbruck. Katalog zur Ausstellung im Tiroler Landesmuseum Ferdinandeum 25. Jänner-22. April 2007. Innsbruck: Tiroler Landesmuseum Ferdinandeum, 2007.

Šašel, J. "Zur Erklärung der Inschrift am Tropaeum Alpium Tropaeum Alpium.«Živa antika 22 (1972): 135-44 (ponatis v: Opera selecta, 1992, 288-97).

Šprajc, I. Arheoastronomija. Arheo. Posebna številka. Ljubljana: Slovensko arheološko društvo, 1991.

Turk, P. »Keltski bojevniki.« V: T. Nabergoj, ur., Stopinje v preteklost: zakladi iz arheoloških zbirk Narodnega muzeja Slovenije. Ljubljana: Narodni muzej Slovenije, 2006.

Turk, P., et al. »New Pre-Roman inscriptions from Western Slovenia. The archaeological evidence.« V: G. Tiefengraber, B. Kavur in A. Gaspari, ur., Celtic Studies II, Protohistoire européenne 11, 47-64. Montagnac: Éditions Monique, 2009.

Vannacci Lunazzi, G. »L'insediamento di Colle Mazéit a Verzegnis. « V: S. Vitri in F. Oriolo, ur., I Celti in Carnia e nellarco alpino centro orientale, 149-60. Trieste: Editreg, 2001.

Vitri, S., in F. Oriolo, ur. I Celti in Carnia e nell' arco alpino cento orientale. Trieste: Editreg, 2001.

Zemmer-Plank, L., in W. Sölder, ur. Kult der Vorzeit in den Alpnen/Culti nella preistoria delle Alpi. Bolzano: Athesia, 2002. 